\title{
EDUCATION SUSTAINABLE DEVELOPMENT-COMMUNITY BASED PROJECTS OF THE PHILIPPINES
}

\author{
Dr. Jestoni P. Babia ${ }^{1}$, Dr. Donna Grace I. Cotejo ${ }^{2}$ \\ ${ }^{1}$ Dean,COE, USJR-Basak Campus \\ ${ }^{2}$ Faculty, CNU-CAS
}

\begin{abstract}
Education for Sustainable Development permits each individual to get the information, abilities, perspectives and qualities important to shape a practical future. This study determined the level of training implementation based on the six ESD action principles and as to which of these principles have contributed to the improvement of the level of implementation of ESD programs in the Philippines, ESD- best practices of the university community extensionists and the challenges that they have met in the implementation of ESD. It centered on Cell's Resilience by Szanton \& Gill (2020), Transformational Learning by Mezirow (1994) and UNESCO's three pillars of ESD and Six ESD Action principles and policy support for sustainable development through community learning centers. This study utilized a quasi-experimental type of research in which it involved quantitative and qualitative data. The random sampling technique was used in order to select the 25 beneficiaries from private and public basic education and higher education institutions. The results showed that the level of implementation was to at least SOME EXTENT with a 3.25 mean, and that only the transformation component is the only significant predictor, the best practices of USJRBlooms, PNU-Mangrove, and CTU-Hablon tapped the decoding of books through Bloom's Software for reading literary , reviving Mangrove Forest through DAGANG fisherfolks to target environmental conservation and MTB literacy, and reviving the Handloom Weaving of Hablon in Argao with socio-economic impact, and the challenges of other extension projects in the Philippines enumerated on the attendance of the beneficiaries and the project team, he change of leaders, organizations, time availability, their limited resources and linkages, financial resource mobilization, sustainability of interest, miscommunication, hectic schedules and negative attitudes towards the extension process. It is concluded that the ESD of the Philippines' implementation is so far, in average level and that the projects have to focus on the transformation of the beneficiaries. This study is recommended to be replicated prioritizing the sustainability and transformation researches, monitoring and evaluation of ESDBased community project researches, proposed plans for wide array of external funding.
\end{abstract}

Keywords

ESD 6 Six Action Principles, Sustainability, Cell Resilience Theory, Quasi Experiment

Article Received: 10 August 2020, Revised: 25 October 2020, Accepted: 18 November 2020

\section{Introduction}

Transformative education aims to reorient and transform societies (Manzini, 2001). Learners with principled knowledge, attitudes and skills will achieve sustainability (UN, 2018; UNESCO, 2015). It empowers them to contribute to environmental sustainability and integrity (UNESCO, ESD Workshop in South East Asia, 2018). Therefore, ESD principles and programs should be promulgated in the Philippines. Henceforth, it creates economic viability and humane society for posterity. This study aims implement ESD-community based projects in the Philippines.

In a report presented by UNESCO in 2011, ESD began in the Philippines since 1950 . Thus, various organization since then have pushed for ESD institutionalization in the country. For instance, the Philippine Rural Reconstruction Movement (PRRM) was established to improve the capacity of rural areas in carrying out sustainability through an integrated program of education and livelihood. Philippine's Department of Environment and Natural Resources (DENR), initiated the program called the Philippine Strategy for Sustainable Development in1989 with the objective to achieve and maintain economic growth without depleting the country's natural resources. Later in 1996, the Philippine Agenda 21 - which is the country's blueprint - was adopted which was later updated in 2009 as the Enhanced Philippine Agenda 21. Such goal of eradicating poverty through good governance was then reflected to the provisions found in the Millennium Development Goals to the current 2030 Sustainable Development Goals. Philippine government managing the education landscape of the country also conducted its huge efforts in achieving the sustainability goals through curriculum integration and mainstreaming. Commission on Higher Education (CHED) articulated ESD integration in its Strategic Plan 
2011-2016 to streamline efforts and resources towards ESD implementation and integration. Department of Education (DepEd) as a response of Hyogo Framework for Action in 2007), issued DO No. 55 on "Prioritizing the Mainstreaming of Disaster Risk Reduction Management in the School System" and DO No. 175 s. 2007 on a technical working group on an operation manual on DRR. At present, Philippine universities awarded by Southeast Asian Ministers Education Organization (SEAMEO) as ESD Fellows namely: University of San Jose- Recoletos, Cebu Normal University, Cebu Technological University and Philippine Normal University have implemented several ESD projects on their own capacity and as a group - implementing community-based ESD programs, creating an ESD center in their own universities, and doing a capacity-building training on community-based ESD to other universities.

USJ-R, being the flagship bearer of UNESCO's Community based ESD Project in the Philippines funded by UNESCO- Japan, the Japanese Government and UNESCO- Bangkok had conducted a training to community- based extensionists in Cebu, to integrate ESD in their institutional community- based works based on ESD's six action principles; (a)responding, (b) engaging (c) enabling (d) embedding (e) transforming and (f) sustaining. Despite huge efforts however, of achieving sustainability in the Philippines reflected through this training, no document and studies have determined how the training has impacted the participants to their communities. No studies have been presented as to why community- based practices where ESD is integrated, could be a laudable practice to ensure that the present and the future generation can be prepared and secured towards sustainability, anchored on sound theories and principles.

Hence, this paper intends to determine the level of training implementation based on the six ESD action principles and as to which of these principles have contributed to the improvement of the level of implementation of ESD programs in the Philippines. Further, this paper also sought the ESD- best practices of the university community extensionists and the challenges that they have met in the implementation of ESD. This direction is aimed at improving the ESD practices in the country, beginning the small initiatives to academic institutions to be cascaded later on to other institutions of learning.

\section{Theoretical Framework}

This study centers around Cell's Resilience Theory by Szanton \& Gill (2020), Transformational Learning Theory by Mezirow (1994) and UNESCO's three pillars of ESD and Six ESD Action principles and policy support for sustainable development through community learning centers.

Cell' resilience theory discusses the delineating factors of society vis-à-vis personal qualities. This theory, beginning with the development of the cellular function of a person could eventually affect his or her physiology and individual-self which then affects community, family and society. From cell as the basic unit of society to maintaining and creating a good physiology, an individual self becomes successful in advocating and involving in capacity- building initiatives towards sustainability. For instance, when an individual advocate for social capacity, then resilience is demonstrated. When preservation and conservation of environmental resources for the use of future generations is manifested, societal resilience is seen. (Mayena, 2006). Such that, resilience towards societal transformation is achieved. As transformation for sustainable development also creates challenges and opportunities, this theory can help individuals and society to achieve the goal for transformation by becoming resilient and dynamic in the process.

ESD as a transformational education addresses the learning outcomes, pedagogy and the learning environment (UNESCO, 2015). Transformational learning is a process of deep, constructive, and meaningful learning that goes beyond simple knowledge acquisition and supports critical ways of making a learner's meaningful life towards community transformation. As Manzini (2001) puts it, the transition towards sustainability is a "social complex learning process", that is, behavior, patterns, values and aspirations dramatically change. Schools in this context must therefore lead in facilitating and addressing gaps between theory and practice in community development.

Transformational Learning Theory is a constructivist approach, focusing on learnercentered approaches where learners are exposed to hands-on activities. Moreover, it is an orientation 
investigated, tabulated, and analyzed.

\subsection{The Level of Implementation of the 6 ESD Action Principles}

6 ESD Action Principles

\begin{tabular}{lcrl}
\hline Responding & 3.29 & 1.26 & Some Extent \\
Enabling & 2.62 & 0.76 & Some Extent \\
Engaging & 3.85 & & Great Extent \\
& & 0.92 & \\
Embedding & 3.81 & .90 & Great Extent \\
Transforming & 2.51 & 1.27 & Less Extent \\
Sustaining & 3.44 & & Great Extent \\
Over-All Mean & $\mathbf{3 . 2 5}$ & .99 & Some Extent \\
& & $\mathbf{1 . 6 3}$ & \\
\hline
\end{tabular}

The Table 1 showed the over-all mean of the implementation of the 6 (six) ESD action principles to the ESD based programs with a mean of $\mathbf{3 . 2 5}$ and an SD of 1.63 and was interpreted as Some Extent. It meant that the 6 six action principles namely responding, enabling, engaging, embedding, sustaining, and transforming were practiced at some point of their ESD programs.

Five $(5 \%)$ percent of the projects responded to the economic, socio-political, cultural, and environmental issues to Some Extent. The projects like the CNU E-Help, CTU-Hablon, CTU TAhi-Sastre, UV Project sa Pakigdait, CTU Mananagat, CTU E-Tech, and Waste into Sustainable Handicrafts were able to empower women to have their own means of living while the PNU-Mangrove Planting, and Deped bus also transformed the lives of men beneficiaries. The USJR-Bloom, USC Talaandig Tribe, PARA Teacher and Deped E-Bus were able to respond to the needs of the children when it came to educational literacy. Ten $(10 \%)$ percent of the projects were able to respond to the cultural issues of some communities to rekindle the lost ethnic cultures of weaving and preserve the languages of particular places. When it came to responding specifically to environmental issues, only PNUMangrove and CTU-Mananagat, and Waste into Handicrafts projects who strictly implemented the 3R's and waste segregation, and city ordinances strictly with fines for violators. Although the projects were somehow responsive, they needed to intensify the project's purposes to emphasize on solving the mentioned issues that needed to be addressed equally.
Twenty (20\%) percent of the projects had an enabling capacity to a great extent to make the projects sustainable. The USJR-Bloom, PNUMangrove, and CTU-Hablon projects had a strong funding to have skills trainings. PNU-Mangrove and CTU-Hablon were able to gather an institutional funding from General Appropriations Act from 9,000.00-100,000.00 to be able to buy shared facilities and modern technology. USJRBloom had a budget of 4.3 million from USAID and University Research Funding. However, (80\%) of the ESD-Community Based Programs had enabling mechanisms to some extent only. Although they were able to promote and advertise through various forms of media for market access, they still needed to mobilize community and large organizations so that the listed mechanisms would be strengthened.

The level of the engagement of the agencies was implemented to a great extent with a grand mean of 3.85. It implied that the community beneficiaries and the local government units were very engaged in their participation of their projects. The local government units such as the local municipalities and barangays actively joined and participated in the promotion of these activities. During the implementation of these projects, the LGUs have showed (80\%) eighty percent attendance and strong support that contributed to the success of the ESD projects. The community stakeholders, non-government organizations, and individual benefactors have a spirit of volunteerism to attend various fora and orientations of the ESD projects and ESD action principles. The level of embedding was implemented to a great extent with an average grand mean of 3.81. The USJR, CTU, and PNU clearly embedded these principles in their 
curricula through tapping their students by training them to help in the community extension as well, and having them attended a number of at least 5 sessions in a semester to be able to understand ESD. It was embedded in the objectives setting, process implementation, engaging community beneficiaries, and monitoring and evaluation. Seventy (70\%) percent of the projects were brought inside the universities for the students to be socially aware and responsible of the environmental issues and helped the community attain literacy through making leveled decodable books in various languages such as that of Blooms Software spearheaded by the USJR- College of Education. Through the embedding of ESD in the curriculum, the projects were able to expand and sustain the level of education, active involvement, and engagement of the community beneficiaries to the said projects.

The level of transformation was implemented to less extent with an average grand mean of $\mathbf{2 . 5 1}$. The transformation was feasible through personal change of character and values after attending series of sessions of community extension projects. (10\%) Ten percent of the beneficiaries were more immersed on the projects because the beneficiaries understood their worth and their contribution to the projects that in return would give them economic income. Ninety percent (90\%) of the beneficiaries were thankful that the universities were helping them create and augment their means of livelihood. However, the transformation was not taking place in $(100 \%)$ swing because most of the projects were still new. Fifty percent $(50 \%)$ of the beneficiaries might be aware of these projects but had a hard time committing themselves due to their hectic schedules, and in looking for another job as well. At times, they had a hard time maintaining a regular attendance. At present, only USJR, CTU, and PNU institutionalized their policies so that the community extension-based projects were protected. The results implied that the projects were still working on encouraging LGUs and other organizations to transform the projects to institutionalized directions, practices, and policies according to some project leaders.

The (15) fifteen out of eighteen (18) ESDCommunity based projects conducted series of trainings to capacitate their beneficiaries. The projects were able to create partnerships with UNESCO, DENR, DTI, LGUs and NGOs, Business Enterprises, Select Municipalities, and Barangays. In general, these 15 were sustainable to a great extent. Furthermore, the CTU-Hablon, USJR-Bloom, and PNU Mangrove projects with an average mean of 4.6. had a high level of sustainability which was implemented to a very great extent. These projects had a high budget from USAID, institutional funding, private and public institutions with good promotional strategies of the products. These projects were also cultural, environmental, educational, and socio-economical in nature. It was implied that the participating institutions had good background of the community projects but not fully aware that they were actually ESD-laden based principles.

With the results of the six ESD action principles, the average mean was implemented to some extent with a 3.25 mean. (80\%) Eighty percent of the said projects are still imbibing the ESD because they are in progress. The results implied that the participating agencies were trying their best to incorporate the ESD community-based projects but they needed to have a regular monitoring and evaluation to ensure that every process went on smoothly and could immediately provide technical assistance to identified challenges in the operations. They had to work out the minorities of stakeholders' involvement for them to fully participate and join skills training. Based on the results, they also needed to create "brand" partnerships to large organizations. Lastly, the sustainability of these projects would be assured if there were strong policies that would protect these policies in the universities so that the projects would not be easily withdrawn and that the beneficiaries would be trained to prepare themselves to be independent from their project teams in the long run.

Which of the 6 action principles contribute to the improvement of the level of implementation of ESD program? 


\begin{tabular}{|c|c|c|c|c|}
\hline \multicolumn{5}{|c|}{ Model Summary } \\
\hline Model & $\mathrm{R}$ & R Square & $\begin{array}{l}\text { Adjusted } \\
\text { R Square }\end{array}$ & $\begin{array}{l}\text { Std. Error of } \\
\text { the Estimate }\end{array}$ \\
\hline & .573 & 0.329 & 0.287 & 0.43128 \\
\hline
\end{tabular}

\begin{tabular}{lll|l|l|l|l} 
ANOVA & \multicolumn{2}{l}{ Sum of } & & Mean & & \\
Model & & $\begin{array}{l}\text { Sum } \\
\text { Squares }\end{array}$ & df & Square & F & P value \\
\hline & Regression & 1.458 & 1 & 1.458 & 7.837 & .013 \\
\hline & Residual & 2.976 & 16 & 0.186 & & \\
\hline & Total & 4.434 & 17 & & & \\
\hline
\end{tabular}

Dependent Variable: ways of sustaining/implementation

Predictors: (Constant), Transformation

\section{Coefficients}

\begin{tabular}{|c|c|c|c|c|c|}
\hline Model & $\begin{array}{l}\text { Unstandardized } \\
\text { Coefficients } \\
\text { B }\end{array}$ & $\begin{array}{l}\text { Std. } \\
\text { Error }\end{array}$ & $\begin{array}{l}\text { Standardized } \\
\text { Coefficients } \\
\text { Beta }\end{array}$ & $\mathrm{t}$ & Sig. \\
\hline (Constant) & 2.796 & 0.250 & & 11.176 & 0.000 \\
\hline Transformation & 0.250 & 0.089 & 0.573 & 2.799 & 0.013 \\
\hline
\end{tabular}

sustaining/implementation

Stepwise multiple linear regressions were used to determine which of the six action principles of ESD greatly contribute to the improvement of the implementation of the ESD programs. Results show that only the transformation component is the only significant predictor. The $\mathrm{R}$ squared value is .329 which indicates that there's only 32.9 percent variance was captured in the model. ANOVA $p$ value is .013 which is also significant, which means that the variables entered have a good fit. Lastly, the coefficients table show that the $p$ value is also significant $(\mathrm{p}=.013)$ which means a significant predictor for implementation, it further states that for every 1 Likert scale increase for transformation the perception of the level of implementation increases by $57.3 \%$.

The results would imply that the transformation has a significant contribution to the perception of the level of implementation of ESDbased projects. In order to perceive these projects as implemented to a very great extent, there must be an alignment of change in the personal directions and goals, university and institutional policies.

\subsection{ESD- Best Practices of the Projects with Sustainability Results}

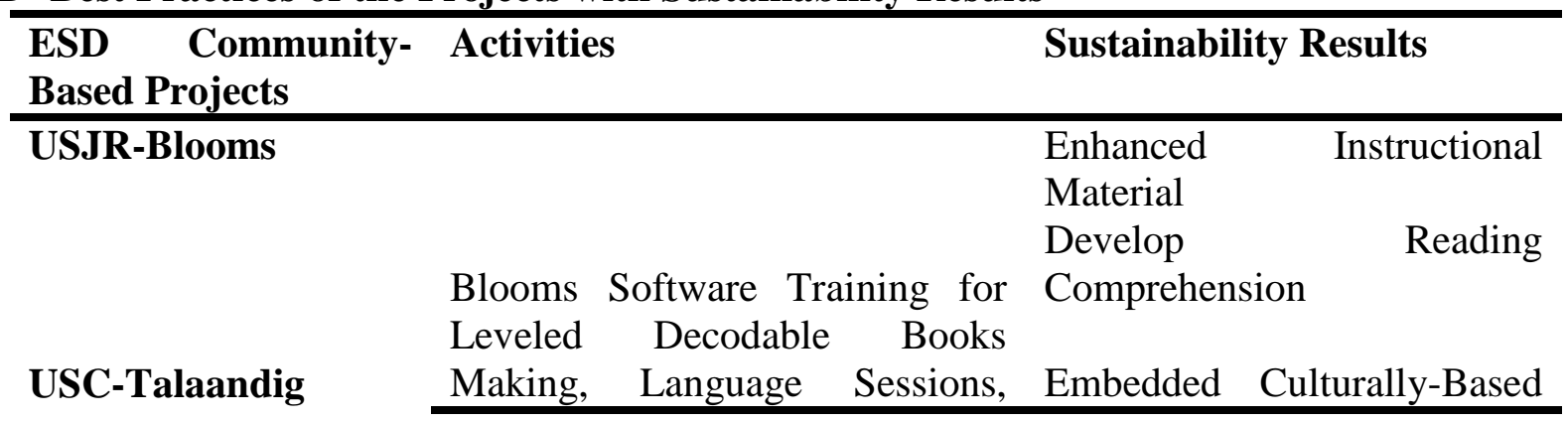




\begin{tabular}{|c|c|c|}
\hline $\begin{array}{l}\text { Tribe } \\
\text { PNU-Mangrove }\end{array}$ & Cultural Activities & Curriculum using their MTB \\
\hline $\begin{array}{l}\text { CTU-Hablon } \\
\text { BSIE Projects } \\
\text { Native Swine } \\
\text { CTU-Saksi sa BJMP } \\
\text { UV-Pakigdait }\end{array}$ & $\begin{array}{l}\text { Skills Training for Weaving, T- } \\
\text { Shirt Production, Poultry } \\
\text { Raising, Machine Operation, } \\
\text { Pattern Making, Handicraft } \\
\text { Making, Technical Skills }\end{array}$ & $\begin{array}{l}\text { Women Empowerment } \\
\text { Economic Returns and } \\
\text { Livelihood } \\
\text { Cultural Reliving } \\
\text { Skilled Beneficiaries } \\
\text { Institutionalized Policies }\end{array}$ \\
\hline $\begin{array}{l}\text { USJR-SHS } \\
\text { DepEd E-BUS } \\
\text { CNU E-Help } \\
\text { Life Projects for } \\
\text { Youth } \\
\text { PARA Teacher } \\
\text { CTU E-Tech } \\
\end{array}$ & 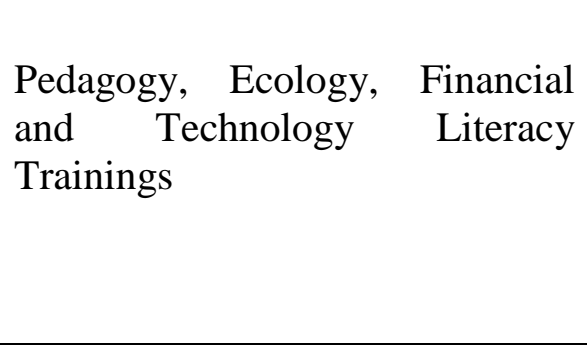 & $\begin{array}{l}\text { Increased Knowledge on } \\
\text { Pedagogy, } \\
\text { Research, and Technology } \\
\text { for } 21^{\text {st }} \text { Century Teaching- } \\
\text { Learning Process }\end{array}$ \\
\hline $\begin{array}{l}\text { CTU-Mananagat } \\
\text { PNU-Mangrove }\end{array}$ & $\begin{array}{l}\text { Environmental Trainings, } \\
\text { Conservation, Planting, Clean- } \\
\text { Up and Rehabilitation }\end{array}$ & $\begin{array}{l}\text { Food Security } \\
\text { Environmental Awareness } \\
\text { Improved Greenbelt Area } \\
\text { Increased Marine Organisms } \\
\end{array}$ \\
\hline
\end{tabular}

The Table 3 showed the best practices of the ESDCommunity Based Projects with their achieved sustainable results. The USJR-Blooms, USCTalaandig Tribe, and PNU-Mangrove conducted activities to teachers and college students on Blooms Software on Leveled Decodable Books using MTB language of their areas. The USJRBloom was able to imbibe the Cebuano-Visayan Language in the Blooms Decodable Books. Through this, the Cebuano-Visayan language was easily understood and the students learned to appreciate the Cebuano-Visayan language.

The PNU-Mangrove project conducted sessions to the teachers on the Blooms Software using the "panginhas" method of the fisher folks so that the environmental protection of mangrove forest would be embedded in the books using Hiligaynon language. Through this, the teachers were able to learn the knowledge from the fisher folks and are transferred to the students of Daga Elementary School who were recipients of the Blooms Software Leveled Decodable Books. They successfully conducted mangrove planting with the help of Department of Agriculture, DENR, PNP, and the Department of Fisheries and Aquatic Resources in Purok Kakahuyan, Brgy. Daga, Cadiz City.
The CTU-Hablon project ensured the $100 \%$ production with the traditional and modern machines in partnership with the LGU. With the raised awareness of its cultural significance of weaving, Hablon de Cebu has gradually caught the attention of the local residents of Argao as they used the hablon products during various occasions such as weddings, festivals, graduations, and the like. The "Argaonon" community wore their own "Hablon" products. However, fifty percent of the $(50 \%)$ of the beneficiaries claimed that not all objectives were accomplished at the end of the year.

The USJR-SHS, DepEd E-BUS, CNU E-Help, Life Projects for Youth, and PARA Teacher accomplished $100 \%$ trainings on Pedagogy, Ecology, Technology, and Financial Literacy Programs and were able to train their target beneficiaries. As perceived by $80 \%$ of the beneficiaries, the time allocated in the mentioned training was sufficient enough for sessions to achieve its specific objective, as well as the location or venue, which was conducive to the training.

With the infusion of the best practices such as new technology in the skills, literacy, and environmental awareness trainings, many community beneficiaries were able to produce new products, create innovative materials and 
marketing strategies, and conserve environmental protection. As a result of these activities, they were able to raise a $50 \%$ income from the usual $10 \%$ of income of the beneficiaries.

\subsection{Challenges in the Implementation of the ESD trainings}

There were a number of challenges met during the implementation of the ESD trainings to the 25 participants. The change of leaders, organizations, time availability, their limited resources and

\begin{tabular}{lc}
\hline ESD Community-Based Projects & Challenges \\
\hline Projects from Private and Public Institutions & Time Availability \\
Projects from Basic Education Institutions & Regular Attendance \\
& Miscommunication \\
Projects from Higher Education Institutions & Community Linkages \\
& Weather Factor \\
& Sustainability of Interest \\
& Funding Number of
\end{tabular}

Filipino attitude linkages, financial resource mobilization, sustainability of interest, miscommunication, hectic schedules, attitudes of the Filipinos, and regularities of attendance have somehow affected their community extension projects and the project team themselves.

\subsection{Challenges and Opportunities of the ESD Projects on the ESD trainings}

According to the project teams from private and public institutions, the time availability and the regular attendance of the beneficiaries and the project teams were hard to match. It could cause a slow progress of the project. Miscommunication and slow work ethics of some government personnel's also affected the pacing of the training sessions of ESD. The project teams from basic education institutions pointed out that miscommunication, reaching out to community, and weather factors were inevitable circumstances that continued to challenge the training sessions. The planning and conceptualization of the project itself could also be a challenge because it involved the Filipinos' passivity to change, limited number of participants and their attendance, and their sustainability of interest affected the projects from higher education institutions. All of the projects unifying responded that funding and people's attitude were top two challenges in the running of these project plans.

It clearly meant that the members of the project teams exhausted their budget within the particular activities, revisited the ESD-Extension's outcomes and objectives, adjust irregular time schedules, invited more teachers to join extension groups, and tapped LGUs and non LGUs for communitybased ESD projects, conducted workshops on COPAR (Community Organizing and Participating) to address these challenges.

As of the change of organizational leadersthe new officers must be trained to catch up with the current status of the ESD projects.

\section{Conclusion and Recommendations}

The ESD of the Philippines' implementation is so far, in average level and that the projects have to focus on the transformation of the beneficiaries. This study is recommended to be replicated prioritizing the sustainability and transformation researches, monitoring and evaluation of ESDBased community project researches, proposed plans for wide array of external funding.

\section{References}

[1] Al-Bashir, M., Kabir, R., Ismat, R. (2016). The Value and Effectiveness of Feedback in Improving Students' Learning and Professionalizing Teaching in Higher Education. Journal of Education and Practice. Vol.7, No.16. 
[2] Arora, N. (2019). Earth: 50 years challenge. Environmental Sustainability 2, 1-3 https://doi.org/10.1007/s42398-019-00053-5

[3] Alsop, S., Dippo, D., \& Zandvliet, D. B. (2007). Teacher education as or for social and ecological transformation: Place- based reflections on local and global participatory methods and collaborative practices. Journal of Education for Teaching, 33(2), 207-223.

[4] Asia and the Pacific Programme of Educational Innovation for Development Strategies and Methods for Teaching Values in the Context of Science and Technology (APEID). (1993).

[5] Barrios, R. E. (2016). Resilience: A commentary from the vantage point of anthropology. Annals of Anthropological Practice, 40(1), 28-38.

[6] Bonanno, G. A. (2004). Loss, trauma, and human resilience: Have we underestimated the human capacity to thrive after extremely aversive events? American psychologist, 59(1), 20.

[7] Boehnert, J. (2011). Transformative learning in sustainable education. Design Research Society: Experiential Knowledge Special Interest Group: SkinDeep, 11.

[8] Byrd, Christy M. (2016). Does Culturally Relevant Teaching Work? An Examination from Student Perspectives. Research Gate.

[9] Dannenberg, S., \& Grapentin, T. (2016). Education for sustainable development-learning for transformation. The example of Germany. Journal of Futures Studies, 20(3), 7-20.

[10] Dotson, R. (2016). Goal Setting to Increase Student Academic Performance. Journal of School Administration Research and Development. Volume 1., No.1.

[11] Department of Education and Early Childhood Development (EECD). (2012). Strength-based Approach.

[12] European University Association (EUA, 2020). LEARNING \& TEACHING PAPER \#11 Evidence-based approaches to learning and teaching

[13] Jackson, M. G. (2011). The real challenge of ESD. Journal of Education for Sustainable Development, 5(1), 27-37.

[14] Kashdan, T. B., \& Fincham, F. D. (2004). Facilitating Curiosity: A Social and SelfRegulatory Perspective for Scientifically Based Interventions. In P. A. Linley \& S. Joseph (Eds.), Positive psychology in practice (p. 482-503). John Wiley \& Sons, Inc.

[15] Kitchenham, A., The Evolution of John Mezirow's Transformative Learning Theory,
Journal of Transformative Education, London. Sage, Volume 6, Number 2, 2008.

[16] Keong, C.Y. (2017). Sustainable development: The Nexus of Environmental Sustainability, Values, and Ethics. European Journal of Sustainable Development (2017), 6, 1, 308-324 ISSN: 2239-5938

[17] Kraaijenbrink, J. (2018, Dec.19). What Does VUCA Really Mean?Forbes. https://www.forbes.com/sites/jeroenkraaij enbrink/2018/12/19/what-does-vuca-really mean/?sh=408a545d17d6\&fbclid=IwAR1

W1THysxAMQRtfYqPKaGoS WhLVjVw BQXOKVw7tWKussXMErwOuoFOSq6

[18] Lenglet, F., Fadeeva, Z., \& Mochizuki, Y. (2010). ESD promises and challenges: Increasing its relevance. Global Environment Research, 14(2), 93-100.

[19] Loewenstein, G. (1994). The psychology of curiosity: A review and reinterpretation. Psychological Bulletin, 116(1), 75-98.

[20] Lovren, V.O. (2019). Didactic Re-orientation and Sustainable Development Faculty of Philosophy, University of Belgrade, Belgrade, Serbia. https://link.springer.com/content/pdf/10.1007\%2F 978-3-319-63951-2_209-2.pdf

[21] Mahmud, S. N. D. (2017). Engaging head, heart and hands: Holistic learning approach for education for sustainable development. International Journal of Learning and Teaching. 9(2), 298-304.

[22] Martin, F. and Bollinger, C. D. (2018). Engagement Matters: Student Perceptions on the Importance of Engagement Strategies in the Online Learning Environment. Online Learning Journal - Volume 22 Issue 1.

[23] Mynbayeba, A., Sadvakassova Z. and Akshalova B. (2017). Pedagogy of the Twenty-First Century: Innovative Teaching Methods.

[24] Naz, F. and Murad, H.S. (2017). Innovative Teaching Has a Positive Impact on the Performance of Diverse Students. SAGE Open https://journals.sagepub.com/doi/pdf/10.1177/215 8244017734022 .

[25] Nordmann, A. (2014) Responsible innovation, the art and craft of anticipation, Journal of Responsible Innovation, 1:1, 87-98

[26] Pavlova, M. (2013). Teaching and learning for sustainable development: ESD research in technology education. International journal of technology and design education, 23(3), 733-748.

[27] Picardal, M.T. and Paño, J.D. (2018). Facilitating Instruction of Central Dogma of 
Molecular Biology through Contextualization. Journal of Teacher Education and Research. Volume 13, Number 2.

[28] Tholke J. S, Martens R, and McKenney S. (2019). The Role of Intuition in Pedagogical Tact: Educator Views. British Educational Research Journal. Vol.45, No.6.

[29] Teichler, U. (2004). The changing debate on internationalization of higher education. Higher Education, 48, 5-26.

[30] United Nations Educational, S. a. (2020). Guide for the Effective Dissemination of the AsiaPacific ESD Teacher Competency Framework. Okayama,Japan: Okayama University, Japan with Asia Pacific Cultural Centre for UNESCO.

[31] United Nations Educational, S. a. (2018). Integrating Education for Sustainable Development (ESD) in Teacher Education in Southeast Asia. Paris, France: United Nations Educational, Scientific and Cultural Organization.

[32] UNESCO. (2010). Education for Sustainable Development Lens: A Policy and Practice Review Tool. Education for Sustainable Development in Action Learning \& Training Tools no. $2-2010$ UNESCO Education Sector p.23 values for environmentally relevant attitudes, preferences, and actions show less. Environment and Behavior, 46(2), 163-192.

[33] Vijayalakshmi, M. (2019). Role of Biology Teacher in inculcating Biological Science Values . Research Gate. Conference Paper.

[34] Zimm, C., Sperling, F., \& Busch, S. (2018). Identifying sustainability and knowledge gaps in socio-economic pathways vis-à-vis the Sustainable Development Goals. Economies, 6(2), 20. 